\title{
'Dress Code' Controversy: A Victim of Misogynistic Mindset or Something Else ?
}

Dr Rituparna Bhattacharyya ${ }^{\dagger}$

\section{Abstract}

In the middle of September 2021, a female candidate wearing 'shorts' (the so-called 'half pant'), hailing from Biswanath Chariali, went to Tezpur to appear at an entrance test of Assam Agricultural University (AAU) at Girijananda Chowdhury Institute of Pharmaceutical Sciences (GIPS), one of the agencies of AAU. While the gatekeeper of GIPS gave her access, the invigilator on duty at the examination hall raised eyebrows on her 'dress code' but allowed her to sit in the examination, coercing her to drape a curtain to cover her legs. Doing so, the invigilator not only trespassed into her personal space- her body; humiliated her by lowering her dignity. This perspective is an attempt to revisit the debate of the dress code of Indian women, which refuses to die even in 21st Century India.

Keywords: Shorts/Half-Pants; Dress Code; Indian Women, Misogyny; Assam, India

\footnotetext{
${ }^{\dagger}$ Editor-in-Chief (Joint), Space and Culture, India; Senior Fellow, Advance HE (formerly Higher Education Academy)UK, Email: rituparna.bhattacharyya@accb.org.uk

C2021 Bhattacharyya. This is an Open Access article distributed under the terms of the Creative Commons Attribution License (http://creativecommons.org/licenses/by/2.0), which permits unrestricted use, distribution, and reproduction in any medium, provided the original work is properly cited.
} 


\section{Introduction}

Social and economic changes are ever-changing and pan-cultural phenomena. Thus, alongside other socio-economic transformations, one can witness changes in dress code, which can be considered a normative standard of everyday life. Unfortunately, however, the women often become the victim of the changed 'dress code'the patriarchs, regardless of gender, remain ever-ready to dress the feminine body (Bandyopadhyay and Lahiri, 2012; Bhattacharyya, 2015). Why? Is this a misogynistic mindset? Or Something else?

In the middle of September 2021, a 19-year-old girl was refused access to an entrance test of Assam Agricultural University (AAU) by the invigilator at Girijananda Chowdhury Institute of Pharmaceutical Sciences (GIPS), one of the agencies of AAU, for reaching the test centre at GIPS in 'shorts' or so-called 'half-pant'. In an interview with one of the local media channels, News18.com, the young girl who travelled from Biswanath Chariali to Tezpur, approximately 70 $\mathrm{km}$ (43.5 miles), to take the AAU entrance examination reveals that although she called her father to go to the market to buy a full pant for her; the invigilator came with a curtain; asked her to drape the same to cover her legs and write the exam. In the young girl's words:

I reached Tezpur at 10:30 from my home town. After freshening up at a relative's place I reached the exam centre on time. After the routine checking, they allowed me at the gates. I went upstairs where the exam rooms were. I had all the credentials I needed to carry including the Aadhaar card and the admit card still they asked me to stand aside. When I asked for the reason, they said that short dresses are not allowed

I questioned why I can't wear shorts. There are no mentioned norms in the admit card for the code. They said that it's common sense. I asked the person to speak to my father, which he denied. I asked my father to get me full pants. As I needed to sit for my exam urgently and my father was taking time to reach. They gave me a curtain to warp around and write the exams

(News18.com). ${ }^{1}$

This incident obviously raises several questions - was this girl the only candidate in 'shorts' in the examination hall? Were all the 'male candidates' in full pants? If not, why were the male candidates not asked to sit the same way as the young girl? How ethical is it to apply moral policing on girls' wear? Moreover, what are the institutional protocols/decorum of GIPS when it comes to 'dress code' behaviour? And if at all the institute has a dress code behaviour protocol, were the candidates made aware of this? These are some questions to ponder. However, the young girl has clarified in her testimony that the examination documents did not mention anything about the dress code norms.

Of course, the dress code is place-specific-no individual has a right to defy any institution's 'dress code' protocols even if it is in explicit conflict of 'freedom of choice' of what to wear. For example, the uniforms of - police personnel, defence personnel, nurses, doctors, students attending schools, and many more. Against the backdrop of this strange incident, and that too in a place where the status of women of Assam (as well as entire North East India) is considered to be much better when compared to their counterparts elsewhere in India (Bhattacharyya, 2009; 2013; 2019; 2021), this perspective aims to revisit the 'dress code' question, where it is the women who remain the target.

\footnotetext{
1 News 18.com. Denied Entry for Wearing Shorts, Girl Took Agricultural Entrance by Wrapping Curtain. https://www.news18.com/news/education-career/denied-entry-for-wearing-shorts-girl-took-agricultural-entranceby-warping-curtain-4212569.html
} 


\section{Dress Code and Women's Body: Victims of Violence}

Over time, it remains well documented that Indian women's bodies have been victims of violence over the dress code controversy (BBC News, 2014; Bandyopadhyay and Lahiri, 2012; Bhattacharyya, 2015; Pandey, 2021, a;b;c). For example, in 2014, Bollywood actor Gauhar Khan was slapped in one of the reality TV shows, Mumbai, for wearing a 'short outfit' (BBC News, 2014). Recently, a 17-year-old girl, who crazed Western outfits, was murdered by male members of her own family. In another incident, a 69 year-old-woman faced violence on social media for posting pictures deemed as 'too sexy' (Pandey, 2021c), and similar stories go on. These bizarre incidents, of course, took place in different geographical spaces of India. However, it bears a commonality - regressive mindset of the agents of 'moral policing' triggering women's bodies and labelling them as indicative of 'moral turpitude' (Pandey, 2021b) and object of 'sexual exploitation' (Bhattacharyya, 2009; 2015). Arguably, these are games of 'powerful' versus 'powerless', thus, signalling 'women as a class' as 'subordinate agents'. Speaking of the notion of power, had a female colleague of the invigilator arrived at the examination hall with similar clothing as the young examinee, would the behaviour of the said invigilator on duty be the same? Perhaps not.

However, it is witnessed that the patriarchs of some households (irrespective of gender), especially middle-class households, are increasingly endorsing their daughters/granddaughters and even the daughter(s)-in-law/wife(vies) to wear 'shorts'. Perhaps, these patriarchs have realised that with the change of time, the clothing practices of people also change, and one has to accept this reality even though their mindsets may not be fully ready to approve it. However, it is evident that the vast majority of the 'agents' of moral policing are ignorant of the fact that what they postulate as 'erogenous zones' (BBC, 2014) of modesty and values when it comes to women's dress code behaviour are in actuality legacies of more than 200 years of British Colonialism that shaped the clothing practices of the vast majority of Indian men and women. In her meticulously researched book, Clothing Matters: Dress and Identity in India, published by the University of Chicago Press, Emma Tarlo (1996) demonstrates how the clothing practices of men and women of India changed over 100 years of British Colonialism. Tarlo (1996) indicates that before the 19th Century, the dressing patterns of the Indians, especially the Hindus, comprised chiefly of draped and wrapped clothes. While the males hailing from the elite families, especially those who worked under the British, gradually started adopting the practices of European-styled clothing, the dressing sense of the British agents was ahead of their colonial counterparts as a way of separating them from their colonial subjects (Tarlo, 1996). Tarlo goes on to argue that the adoption of the clothing practices by the elite Indian males "was not so much motivated by admiration for the British as by acceptance of the idea that India's development could be brought about through cooperation with European values and ideas of progress" (Tarlo, 1996: p.320). Gradually, European clothing practices were adopted by common Indian males too across the spectrum of class, caste and religion.

However, women lagged in adopting European style clothing practices. Evidence suggests that even blouse was not a part of Bengali women's clothing practices - British Library Board photo $124 /(36)$ displays Bengali women in Saris over their bare bodies in the early 1860s (BBC, 2014). This observation validates the observation of the clothing practices of women of Assam of those times who wore their traditional Mekhela Sadar along with the Riha (a long piece of rectangular cloth) to cover their bare body, above which they used to wear the two and a half-metre long Sadar, which also served as a ghunghat or orhni (headscarf), in the case of married women. And the Mekhela covered the lower part of the body. The question is, were these women of the time not modest and bore values of Indian culture?

As reported by BBC (2014), the blouses, jackets and chemises, which are parts of dressing practices of contemporary times was 
proselytised by Jnanadanandini Debi, the wife of Satyendranath Tagore, who was the brother of the novel laureate Rabindranath Tagore (07 May 1861-07 August 1941). Jnanadanandini Debi was denied access to the British Raj dominated clubs for wearing the Sari without a blouse. As BBC (2014) reports:

It was Inanadanandini Debi, the wife of Satyendranath Tagore - brother of the famous Bengali poet Rabindranath Tagore - who popularised the blouses, jackets and chemises and the modern style of the sari today after she was reportedly refused entry to clubs under the Raj for wearing the sari fabric over her bare breasts. Tagore is believed to have actively encouraged his wife to adopt Western ideas.

The terms "blouse" and "petticoat" both English - made the leap into Indian vocabulary in the Victorian era. Shirts also came to be worn under the sari as part of high fashion and these rather British innovations are considered traditional garments.

Arguably, who decides the yardstick of modesty for women and men? The connotation of modesty is subjective and space-specific - it changes over time in different geographical regions and communities. "It [is] not always about covering ...face and body, and in many respects, India's hot climate [should be taken into consideration]. People just [follow what is] convenient" (BBC, 2014).

Notwithstanding, the clothing practices of Indian educated women vastly changed with the onset of the neoliberal economic reforms of the 1990s (Bhattacharyya, 2009) as a way to "distance themselves from the backward associations of local dress and join the ranks of the 'progressive'" (Tarlo: 1996: 324) and not to portray themselves as a 'sexual icon'. Closer scrutiny reveals that the reasons for adopting western outfits or European clothing by both

\footnotetext{
${ }^{2}$ Girl forced to cover her legs for wearing shorts for exam in Assam (2021, 17 September). The Hindu. https://www.thehindu.com/news/national/other-
}

Indian males and females are similar-comfort, smart and navigators of the cultural capital (Bhattacharyya, 2009; Tarlo, 1996). However, it is heartening to witness that women's dress code (including the dress code controversy of this examinee at Tezpur entrance examination) often remains a controversial issue because of the increasing projection of women in western or attractive apparel as 'sexual objects' (Bhalla, 2012; Bhattacharyya, 2015). (Un)surprisingly, this form of misogynistic mindset continues to be validated across all cultures and subcultures of the country, including Assam, even though women of Assam's freedom and mobility are perceived as somewhat higher than their counterparts elsewhere (Bhattacharyya, 2019; 2021).

Nonetheless, the mindset of the invigilator at GIPS is beyond misogyny. It can be compared to the attitudes of the Taliban ${ }^{2}$-the invigilator has intruded into her personal space and demeaned her dignity by coercing her to drape the curtain, which is presumably not a washed one and carrier of diseases-another form of violation of human rights. One can only imagine the trauma and pain that the young lady is currently reeling in, the scar of which is assumed to be longlasting, sparking 'vicarious trauma' (intrusive threat) (Dickson-Swift et al., 2007; Das et al., 2020) to millions of young women and girls.

\section{Enquiry into the Incident}

It has come to the surface that the AAU has, constituted a three-membered committee headed by the Dean of the Agriculture Faculty to conduct the investigation and submit its report within ten days. Ten days have already passed, and we eagerly wait for the results of the probe.

\section{References}

Bandyopadhyay, Sarbani and Lahiri Shoma Choudhury (2012). Dressing the Feminine Body. Economic and Political Weekly. 47 (46),

states/girl-made-to-wrap-a-curtain-around-her-legs-forwearing-shorts-for-exam-in-assam/article36515343.ece 
https://www.epw.in/journal/2012/46/commen tary/dressing-feminine-body.html

BBC News (2014, 6 December). Dressing the Indian woman through history. https://www.bbc.co.uk/news/magazine30330693

Bhalla, Abhishek (2012). The Rapes Will Go On. Tehelka.http://old.tehelka.com/the-rapes-willgo-on/

Bhattacharyya, Rituparna (2021). Pierre Bourdieu's Symbolic Violence: Scripting Gender among Assamese Middle-Class Women in Higher Education. In Anindita Dutta (ed.). Gender, Space and Agency in India: Exploring Regional Genderscapes, 15-33, Routledge.

Bhattacharyya, Rituparna (2019). Symbolic Violence and Misrecognition: Scripting Gender among Middle-class Women, India. Society and Culture in South Asia, 5(1), 19-46, DOI:

$10.1177 / 2393861718787870$

Bhattacharyya, Rituparna (2015).

Understanding the Spatialities of Sexual Assault against Indian women in India, Journal Gender, Place and Culture: A Journal of Feminist Geography, 22(9), 1340-1356 DOI:10.1080/0966369X.2014.969684

Bhattacharyya, Rituparna (2013). Are We Empowered? Stories of young Indian working women. Lap Lambert Academic Publishing Bhattacharyya, Rituparna (2009). Examining the Changing Status and Role of Middle-Class Assamese women: Lessons from the Lives of University Students. PhD thesis. Newcastle
University, UK.

https://theses.ncl.ac.uk/jspui/handle/10443/30 3.

Das, Tulshi Kumar, Bhattacharyya, Rituparna, Alam, Fakrul, and Parvin, Amina (2020). Indepth Semi- structured Interviewing: Researching Domestic Violence as a Public Health Issue in Bangladesh, SAGE Research Methods Cases Medicine \& Health, Disciplines: Public Health. DOI: https://dx.doi.org/10.4135/9781529719840

Dickson-Swift, V., James, E. L., Kippen, S., \& Liamputtong, P. (2007). Doing sensitive research: What

challenges do qualitative researchers face? Qualitative Research. 7, 327-353. doi:10.1177/ 1468794107078515

Pandey, Geeta (2021a, 27 July). The Indian girl killed for wearing jeans. BBC News.

https://www.bbc.co.uk/news/world-asia-india57968350

Pandey, Geeta (2021b, 22 March). Why India is talking about ripped jeans and knees. $B B C$ News. https://www.bbc.co.uk/news/world-asiaindia-56453929

Pandey, Geeta (2021c, 15 January). Rajini Chandy: The 69-year-old Indian actress trolled for 'too sexy' photos. $B B C$ News.https://www.bbc.co.uk/news/world-asiaindia-55644055

Tarlo, Emma (1996). Clothing Matters: Dress and Identity in India. Hurst \& Company 